\title{
Testing the Energy-Environmental Kuznets Curve Hypothesis in the Renewable and Nonrenewable Energy Consumption Models in Egypt
}

\author{
Haider Mahmood ${ }^{1, * \mathbb{D}}$, Tarek Tawfik Yousef Alkhateeb ${ }^{2}$, Muhammad Tanveer ${ }^{3}$ (D) and Doaa H. I. Mahmoud ${ }^{4}$ \\ 1 Department of Finance, College of Business Administration, Prince Sattam bin Abdulaziz University, \\ Alkharj 11942, Saudi Arabia \\ 2 Department of Agricultural Economics, Kafrelsheikh University, Kafrelsheikh 33511, Egypt; \\ tkhteb1@gmail.com \\ 3 Prince Sultan University, Rafha Street, Riyadh 11586, Saudi Arabia; mtanveer@psu.edu.sa \\ 4 Economics and Agribusiness Department, Faculty of Agriculture, Alexandria University, \\ Alexandria 21545, Egypt; doaa.mahmoud@alexu.edu.eg \\ * Correspondence: h.farooqi@psau.edu.sa; Tel.: +96-61-1588-7037
}

Citation: Mahmood, H.; Alkhateeb, T.T.Y.; Tanveer, M.; Mahmoud, D.H.I. Testing the Energy-Environmental Kuznets Curve Hypothesis in the Renewable and Nonrenewable Energy Consumption Models in Egypt. Int. J. Environ. Res. Public Health 2021, 18, 7334. https:// doi.org/10.3390/ijerph18147334

Academic Editor: Chi-Chung Chen

Received: 2 June 2021

Accepted: 6 July 2021

Published: 8 July 2021

Publisher's Note: MDPI stays neutral with regard to jurisdictional claims in published maps and institutional affiliations.

Copyright: (c) 2021 by the authors. Licensee MDPI, Basel, Switzerland. This article is an open access article distributed under the terms and conditions of the Creative Commons Attribution (CC BY) license (https:// creativecommons.org/licenses/by/ $4.0 /)$.

\begin{abstract}
The Environmental Kuznets Curve (EKC) association between income and pollution emissions proxies has been extensively tested in the environmental literature. However, testing of the energy-EKC is scanty. This present research examined the energy-EKC in the cubic relationship of economic growth and different renewable and nonrenewable energy proxies in Egypt from 1965-2019. In the long run, we corroborate the N-shaped relationships in the case of primary energy, oil, and coal consumption models, and confirm the long run energy-EKC association in these energy proxies. Moreover, we find turning points of the N-curve for these energy sources in 1998, 2000, and 1979-2005, in primary energy, oil, and coal consumption models, respectively. Hence, economic growth is responsible for increasing nonrenewable energy consumption and has environmental consequences in Egypt. In the short run, we find N-shaped relationships in the case of primary energy, oil, and coal consumption. Further, we find an inverted U-shaped relationship in the case of natural gas consumption. In addition, we corroborate an inverted N-shaped relationship in the case of hydroelectricity consumption, a renewable energy source. Hence, we confirm the short-run energy-EKC relationship in all investigated renewable and nonrenewable energy proxies.
\end{abstract}

Keywords: energy-EKC; economic growth; primary energy consumption; oil; coal; and natural gas consumption; hydroelectricity consumption

\section{Introduction}

Economic growth raises energy consumption and pollution emissions during the first phase of development, called the 'scale effect'. Later, it may also reduce the quantity or type of energy demand and reduce pollution emissions. This can be due to the technique effect, where the latest clean technology may reduce energy demand and pollution. Moreover, pollution-oriented production would tend to be replaced by clean products, and the composition effect would help to reduce pollution emissions [1]. The phenomenon of increasing pollution at the first stage and decreasing at the second stage is termed the environmental Kuznets curve (EKC) hypothesis [2], based on Kuznets [3]. This reflects an inverted U-shaped association between economic growth and pollution, shown in Figure 1. Therefore, the quadratic effect of income growth on pollution may be tested to verify the EKC hypothesis. Moreover, another stream of the EKC literature has tested the cubic impact of income on pollution emissions, which portrays a positive effect of growth in the first stage, a negative impact in the second stage, and a positive impact in the third stage of development. This phenomenon is the N-shaped EKC [4], shown in Figure 1. 


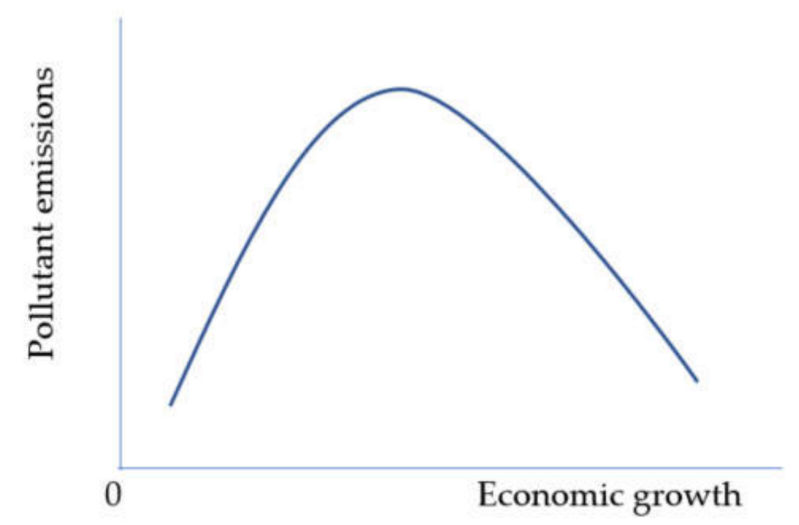

Inverted-U-Shaped EKC

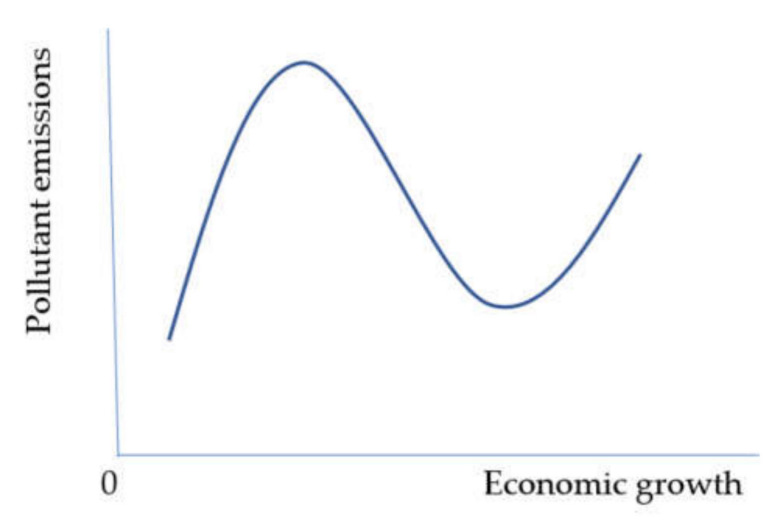

N-Shaped EKC

Figure 1. The EKC.

The literature has probed the above types of EKC using different proxies for pollution emissions, various determinants of pollution emissions along with economic growth, and different methodologies. In empirical testing, the relationship of economic growth with emissions in the form of carbon, sulfur, nitrogen, greenhouse gases (GHGs), and the ecological footprint is varied. This can be a monotonic, inverted U-curve, U-curve, $\mathrm{N}$-curve, inverted $\mathrm{N}$-curve, or no relation. The monotonic nature reveals the linear impact of economic growth on any form of emission, which can be increasing or decreasing, while the squared and cubic terms of income should appear insignificant. A significant increase in emissions accompanied by a significant initial fall in emissions due to a substantial increase in income provides us with evidence of an inverted U-curved relation. If emissions again later increase, this would be defined as an $\mathrm{N}$-curve relationship [5]. Opposite cases have also been reported in the literature, designated as a U-curve [6] and inverted N-curve between growth and emissions [7]. In the relationships discussed above, an inverted U-curve and $\mathrm{N}$-curve may be claimed in order to validate the EKC hypothesis [8,9].

The literature has also inspected the EKC between energy use and economic growth, termed energy-EKC (EEKC). This EEKC testing is more relevant in countries that depend on nonrenewable energy consumption intensively. The literature has investigated the EEKC in the quadratic and cubic relationship between energy and growth. For instance, in a panel study, Suri and Chapman [10] initiated empirical testing of the EEKC. They argued that manufactured exports, imports, and gross domestic product (GDP) significantly affected energy consumption and economic growth, because manufactured exports and imports changed the structure of the economy in terms of production. For instance, manufacturing imports may reduce local production and energy consumption. On the other hand, manufacturing exports may increase local production and energy consumption. Hence, manufacturing imports may reduce the manufacturing GDP, manufacturing exports may increase the manufacturing GDP, and both might shape the economic structure in terms of manufacturing. Empirical testing corroborated the inverted U-curve between GDP and energy use, hence validating the EEKC hypothesis. Moreover, the positive effects of manufacturing GDP and exports and the negative effect of manufacturing imports were found on energy consumption. Thus, the manufacturing structure of the economy did matter regarding energy consumption. Aruga [11] investigated the EEKC in 19 Asian countries regarding the quadratic relationship of GDP and energy consumption. The EEKC was corroborated in high-income Asian countries, while EEKC was not substantiated in middle-income economies. Hence, energy transition was only found in the case of high-income Asian countries.

In country-specific studies, Hundie and Daksa [12] investigated the EEKC in the quadratic settings between growth and energy intensity in Ethiopia from 1974-2014. They validated the EEKC and found positive effects of urbanization and foreign aid on energy intensity. However, the impact of imports was negative, and the effect of industrial GDP 
on energy intensity was insignificant. Aboagye [13] investigated the quadratic relationship between energy variables and growth in Ghana from 1981-2014. The EEKC was validated in both models of energy consumption and intensity. Moreover, urbanization, industrial activities, and trade openness raised energy consumption, while Foreign Direct Investment (FDI) helped to reduce it. On the other hand, industrial activities and FDI had positive effects on energy intensity.

Later, the literature started to probe the cubic relationship between growth and energy variables. For instance, Luzzati and Orsini [14] explored the N-curve between absolute energy use and income in 113 countries from 1971-2004. They could not validate the EEKC in empirical testing of the whole panel. However, they found positive effects of income and income-cubic terms and an insignificant impact of income-square on energy use in 36 low-income countries. The positive and negative effects of income-square and income-cubic terms were found on energy use in 38 middle-income and nine oil-producing countries. In contrast, the effect of the income-linear term was insignificant. Moreover, the positive and negative effects of income and income-cubic terms were found on energy use in 25 high-income countries. In contrast, the impact of the income-square term was insignificant. Hence, evidence for EEKC was not validated in any investigated group of countries. Pablo-Romero and De Jesus [15] examined EEKC in 22 American economies during 1990-2011. They found positive effects of linear, squared, and cubic terms of gross value added to absolute energy consumption. Hence, EEKC was not validated in the investigated region.

Egypt is a significant energy consumer and the leading producer of oil and gas in Africa. Figure 2 shows the percentage of different sources of energy consumption, i.e., oil consumption (OC), natural gas consumption (NGC), coal consumption (CC), and hydroelectricity consumption (HC). The data on all energy sources are taken from BP [16], expressed in exajoules and converted into a percentage of total energy consumption (TEC). The boxplot of OC shows that minimum, median and maximum values are $39.28 \%, 67.18 \%$, and $90.85 \%$ of OC in TEC. The maximum value is observed in 1966 . Afterward, oil consumption declines but accounts for more than $50 \%$ of TEC till 2001 and around $40 \%$ in 2018-19. In the same way, coal consumption has an average negative trend in the sample period, after touching a peak in 1969. The boxplot of CC shows that minimum, median and maximum values are $0.47 \%, 2.42 \%$, and $7.59 \%$ of CC in TEC. Natural gas consumption has the opposite trend compared to oil and coal consumption. The average trend of NGC is positive in the sample period, significantly jumped after 1998. The minimum, median and maximum values are $0.39 \%, 23.67 \%$, and $55.43 \%$ of NGC in TEC. Natural gas consumption generally emits less $\mathrm{CO}_{2}$ emissions than oil and coal consumption [17]. Hydroelectricity consumption has an average positive trend during 1965-1975 but has a mostly negative trend afterward. The minimum, median and maximum values are $3.08 \%, 6.90 \%$, and $16.36 \%$ of HC in TEC. In summary of Figure 2, we may observe that Egypt fulfils more than $90 \%$ of energy demand from nonrenewable sources in most sample periods except 1969-1982. Further, Egypt has also been a net importer of oil since 2009 [18]. Hence, energy consumption sources in Egypt may have environmental consequences, and investigation of these energy sources is important during the process of the country's economic growth.

Increasing economic growth is responsible for accelerated energy consumption $[19,20]$. In this situation, it seems pertinent to conduct a comprehensive study to investigate the effect of different phases of economic growth on energy consumption, which can be tested with the cubic EEKC hypothesis. Particularly, Figure 2 shows the importance of EEKC analyses of different energy sources in Egypt, because all energy sources have different trends. In the global literature, the EEKC has been investigated considering a quadratic relationship to energy and growth [10-13] and considering a cubic relationship to energy and growth [14,15,20-22]. In the case of Egypt, the literature has investigated the linear impact of income on energy consumption, ignoring these quadratic or cubic relationships $[19,20,23,24]$. Hence, the testing of EEKC in the relationship between growth and energy is absent in the Egyptian literature. However, some studies have investigated the 
EKC between economic growth and emissions, considering a quadratic relationship [25-31]. Therefore, the Egyptian literature omits testing of the EKC in its cubic relationship to economic growth and emissions and has ignored the EEKC in both quadratic and cubic relationships of economic growth and energy variables. In the present state of the art, this study aims to test the EEKC in the cubic relationship of economic growth and energy consumption to fill this literature gap. To ensure a comprehensive empirical contribution, the EEKC is tested in disaggregated renewable and nonrenewable energy sources, using a maximum time sample of 1965-2019.

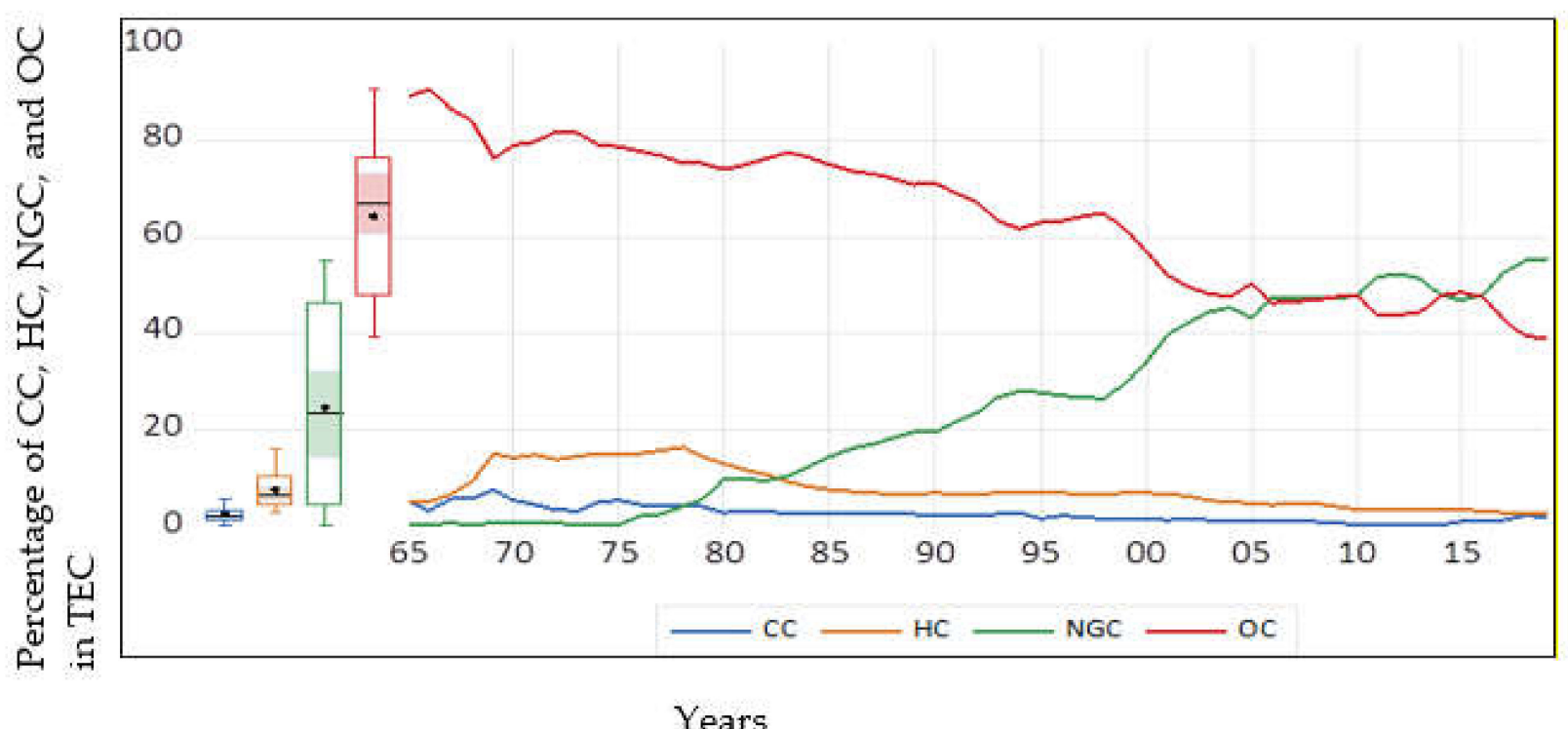

Figure 2. Trends of Energy Sources.

The rest of the study is ordered as follows: a thorough discussion is carried out on the empirical findings of various scholars in Section 2. In Section 3, sources of data, models, and econometric methods are discussed. Section 4 provides details of the empirical findings. The last and final section sheds light via concluding remarks.

\section{Literature Review}

Grossman and Krueger [1] initiated the testing of the EKC between economic growth and different proxies of emissions. They investigated the role of the North American Free Trade Agreement (NAFTA) on pollution emissions. They found that trade reduced emissions in high-income economies and increased emissions in low-income economies. Hence, the level of development and trade are responsible for the environmental quality of an economy. Increasing exports would increase the size of the economy and could pollute the environment through the scale effect in the first stage of development. Later, with increasing levels of development, trade might shift pollution-oriented production from a rich economy (with strong environmental regulations because of a demand for a cleaner environment) to a poor economy (with weak environmental regulations) [32], termed as the Pollution Haven Hypothesis (PHH). Heckscher-Ohlin's (H-O) theory also explained that free trade promoted labor and natural resource-intensive activities in developing countries and human capital-intensive activities in developed countries. Hence, such specialization might shift pollution from high to middle-income countries [33]. In this context, SaintPaul [34] argued that poor economies tend to be a net exporter of pollution-oriented products and vice versa in the case of rich economies. Hence, pollution-oriented industry would be displaced from developed to developing countries, changing the composition of these economies [35]. Thus, trade would shift developed economies from the first to the second stage of the EKC. The second stage of the EKC starts once the technique and composition effects dominate the scale effect within the economy [36]. Moreover, 
trade would also help developing economies to shape their EKC. For instance, trade could improve the economic growth of developing economies, which might demand tight environmental policies due to the demand for a cleaner environment [37].

Arrow et al. [38] argued that the EKC theory assumed economic growth as an exogenous variable. Hence, the EKC considered only a one-way relationship, from economic activities to emissions. However, it ignored the possible feedback effect between environment and economic growth because environmental damage might also reduce economic growth due to demand for tight environmental policies. In a piece of empirical evidence, Coondoo and Dinda [39] found a feedback effect between $\mathrm{CO}_{2}$ emissions and economic growth in developed economies. However, this feedback effect was not found in developing economies. Hence, any environmentally sustainable policy might reduce economic activities in a developed economy. Moreover, the environmental policy might also shift pollution activities from developed to developing countries [40]. In addition, Stern [41] provided some econometric criticism of the EKC estimation, i.e., simultaneity, heteroskedasticity, cointegration issues, and omitted variables bias. These econometric problems were mostly suggested in panel models' estimations, ignoring time or cross-sectional effects. Moreover, Stern and Common [42] pointed out that time or cross-sectional effects could be correlated with income level and square variables. Stern [41] suggested the decomposition and frontier model approach using linear programming, assuming best-practice technologies on the frontier. Frontier models did not need sectoral fuel consumption data. In the same way, Millimet et al. [43] proposed the semi-parametric approach to reduce the peaks of the inverted U-shaped relationship. Grossman and Krueger [36] proposed a decomposition approach to study emissions, from GDP, emissions intensity, and sectoral share in GDP, which was later augmented by including fossil and non-fossil fuel.

Ignoring EKC, the literature has investigated the relationship between energy consumption and economic growth via causality analysis and reported different conclusions. For example, Akkemike and Göksal [44] found a two-way relationship between GDP and energy consumption and corroborated the feedback hypothesis in most of their investigated countries. On the other hand, Payne [45] could not validate any direction of the relationship between energy consumption and economic growth and confirmed the neutrality hypothesis. Moreover, Ouedraogo [46] reported the one-way long-run relationship between energy consumption and economic growth and corroborated the growth hypothesis in the long run. However, one-way short-run causality was found from GDP to energy consumption, and the conservative hypothesis was verified in the short run. Further, Huang et al. [47] found a one-way relationship between economic growth and energy consumption high and middle-income countries and confirmed the conservative hypothesis.

Some literature has also considered both the EKC testing and causality analyses. For example, Shahbaz et al. [48] scrutinized the EKC in Pakistan. This study used a causality test from 1971 to 2009 and confirmed a one-way causation from real income and its square to pollution in the short run. Nasir and Rehman [49] examined the relation between GDP and emissions in Pakistan. After using Johansen's multivariate cointegration and causality test for the data from 1972 to 2008, this study observed that GDP enhanced pollution and GDP-squared reduced pollution. Hence, the EKC was corroborated, and the authors also provided evidence of one-way causality running from the GDP and GDPsquared to pollution. Shahbaz et al. [50] tested the EKC for an Indian economy using Bayer and Hanck [51] and ARDL for the sample period from 1970 to 2012. The authors found that increasing growth accelerated emissions. Once income had increased beyond a certain threshold, emissions started to decrease. Hence, the results confirmed the EKC and also reported two-way causality between growth and emissions. Jalil and Mahmud [52] conducted research on testing EKC in China. Using ARDL bounds testing from 1975 to 2005, the study confirmed evidence of EKC along with the quadratic effect of real income on $\mathrm{CO}_{2}$ emissions in China. The study also provided evidence of a causal relationship between real income and its square and emissions. 
Shahbaz et al. [53] considered the nonlinear impact of financial development on emissions in the EKC framework in the UAE. After employing ARDL for the data series from 1975-Q1 to 2014-Q4, the study could not find the EKC in UAE. The study further reported a two-way causal link between both actors. Ozturk and Acaravci [54] explored the EKC in Turkey. After considering the bounds testing approach from 1960 to 2007, the results exposed evidence of the EKC between GDP and emissions. The results further revealed the long-run unidirectional causal relation between GDP and emissions in Turkey. Shahbaz et al. [55] examined the nonlinear impact of real GDP on emissions in Turkey. Using a sample from 1970 to 2010, the authors reported a positive effect of GDP and a negative effect of GDP-squared on emissions. Further, the results displayed a short-run causality between GDP and its square and emissions. In the long run, bidirectional causality between both variables was seen in Turkey. Ozatac et al. [56] explored the EKC in Turkey. After employing the ARDL approach on the data series from 1960 to 2013, the results corroborated the EKC in Turkey. The study also reported one-way causality between growth and emissions.

A vast literature has examined the EKC, ignoring the possible feedback effect between energy and economic growth variables [38]. For instance, Acaravci and Ozturk [57] conducted research on 19 European countries to explore the EKC. The study used the Autoregressive Distributive Lag (ARDL) model from 1960 to 2005 and confirmed the EKC in Denmark and Italy. Madaleno and Moutinho [58] studied the EKC between GHGs and the income of 27 European Union countries. The authors found a U-curve between emission and growth relationships in the models of different GHG emissions in the short run. Moreover, electricity and total energy use had positive effects on most of the investigated emissions. To et al. [59] examined the EKC in emerging Asian countries during 1980-2016. The authors found an inverted $\mathrm{N}$-curve between income and emissions and an inverted U-curve between FDI and emissions.

Javid and Sharif [60] inspected the nonlinear impact of economic growth on emissions. They used the bounds test for the sample from 1972 to 2013 in Pakistan. They found that pollution emissions increased due to an increase in economic growth up to a point. However, beyond this level, it started to decrease as economic growth increased. Hence, they confirmed the presence of the EKC in Pakistan. Murshed et al. [61] tested the nonlinear impact of GDP on GHGs by incorporating control variables such as energy intensity, liquefied petroleum gas, coal, natural gas, oil, and hydropower consumption in Bangladesh. After employing a bound test for a sample from 1980 to 2015, this study provided evidence of the EKC between GDP and GHGs. In the same way, Rabbi et al. [62] inspected the EKC in Bangladesh. The study used Johansen's multivariate approach for the data series from 1972 to 2012 and found a long-run EKC and short-run U-shaped relationship.

Dong et al. [63] examined the EKC in China. The study confirmed cointegration between the emissions and their determinants in China from 1993 to 2016. The long-run results concluded the EKC between real GDP and emissions in China. Ren et al. [64] took 18 industries in China and tested the EKC. Using a sample from 2000 to 2010, the empirical results supported the EKC hypothesis in all selected 18 industries. Farhani and Lorente [65] examined the nonlinear impact of GDP on emissions by taking three control variables in three separate specifications. Using a sample from 1965 to 2017, the empirical results reported a U-shaped relationship using coal and oil consumption as control variables in China. Results also supported the EKC hypothesis in China, controlling gas consumption. The results further disclosed the EKC hypothesis in the USA, controlling coal, gas, and oil consumption. Lastly, no evidence of EKC was found regarding the control of coal and oil consumption in India. However, the EKC was found, controlling gas consumption, in the Indian model.

Saboori et al. [66] explored the EKC in Malaysia. The study used the ARDL approach on the sample period from 1980 to 2008 and corroborated the EKC between emissions and income in Malaysia. Saboori and Sulaiman [67] examined the EKC between income and emissions. The study used the ARDL cointegration approach by using four controls in 
alternate functional forms, such as coal, gas, oil, and electricity consumption, on the data series from 1980 to 2009 and found evidence of the EKC in Malaysia. Marques et al. [68] inspected the persistence of EKC in Australia. The study considered the bound test for the sample from 1965 to 2016 and witnessed the long-run EKC hypothesis. The U-formed relation was evident in the short run, which established an absence of the short-run EKC in Australia. Pata [69] conducted research testing the EKC between real income and emissions in Turkey. The results provided evidence of the EKC in Turkey for a sample from 1971 to 2014.

Bilgili et al. [70] scrutinized the EEKC between growth and energy intensity in Asia. After employing an augmented mean group estimator on the sample from 1990 to 2014, the results provided evidence of the EEKC in Malaysia, India, Nepal, China, Indonesia, Vietnam, and the Philippines. However, the EEKC was not evident in Thailand, Bangladesh, and South Korea. In Panel, the study further provided evidence of one-way causation from growth to energy intensity. Kander et al. [71] considered consumption-based energy rather than a production-based approach in order to test the relevance of the EEKC in seven European economies. After using a sample from 1870 to 1935, the study found evidence of the EEKC between income and production-based energy intensity in Germany and the Czech Republic. The study further reported a slight bottom-up U-curve in Portugal but a flat long-run bottom-up U-curve in the case of Great Britain. The study exposed that the EKC was not evident in Italy, Denmark, and Sweden and found evidence of EEKC between growth and consumption-based energy intensity in Portugal. A slight bottom-up U-curve was prominent in Germany, and EEKC between income and consumption-based energy intensity was not found in Denmark, Italy, Sweden, and Great Britain. It concluded that the EEKC was relevant to production-based energy intensity, while it became weak or almost irrelevant in the case of consumption-based energy.

Considering spatial autocorrelation, Li et al. [21] investigated the 21 regions of China from 2000-2017 to test the cubic relationship between growth and different energy sources, controlling urbanization, industrialization, and population density. They corroborated the inverted N-shaped relationship in oil, gas, coal, and total energy consumption models. Moreover, the positive effects of industrialization and population density on energy variables were found. However, the negative impact of urbanization was seen. In the same way, Ge et al. [22] investigated the impacts of income and urbanization on nitrogen oxide in the Chinese regions, considering spatial autocorrelation. The authors corroborated the inverted $\mathrm{N}$-shaped relationships between emissions and income and between urbanization and emissions. Moreover, energy intensity accelerated these emissions.

Ignoring the EEKC, the literature has investigated the EKC between growth and emission relationships in Egypt. For instance, Ibrahiem [25] studied the EKC between $\mathrm{CO}_{2}$ emissions and income during 1980-2010. The EKC was not validated in the empirical exercise. Moreover, energy consumption positively affected emissions, and population and trade openness negatively affected emissions. Moreover, bidirectional causality was found between emissions and growth. Mahmood et al. [26] probed the EKC in Egypt during 1990-2014, controlling trade, FDI, and energy use. Energy use showed a positive impact on emissions, and FDI negatively affected emissions, while trade showed an insignificant effect. Moreover, the EKC was found valid between emissions and growth. El-Aasar and Hanafy [27] examined the EKC between GHGs and growth in Egypt during 1971-2012, controlling trade. The EKC was not validated, and trade showed an insignificant effect on GHGs.

Onafowora and Owoye [72] investigated the EKC in eight countries' time-series analyses, including Egypt. They corroborated the quadratic EKC in Japan and South Korea and the N-shaped EKC in other countries. Moreover, a positive effect of population density on emissions was reported in five out of eight investigated countries. Beşe and Kalayci [28] examined the EKC in Egypt, Turkey, and Kenya from 1971-2014. The EKC was not validated in all investigated countries. However, energy consumption caused the growth in Egypt and Kenya. Moosa [29] investigated the EKC in the quadratic effect of income 
on $\mathrm{CO}_{2}$ emissions in Jordon, Tunisia, Algeria, and Egypt during 1960-2014. The study found the EKC in all investigated countries. Using data from 1980-2014, Ahmed et al. [73] investigated the EKC in eight developing countries, including Egypt. The estimations corroborated the EKC in the panel and five out of eight counties' time series results. However, the EKC was not validated in Egypt, Indonesia, and Malaysia. Moreover, imports and energy usage had positive effects on emissions.

Sghaier et al. [30] investigated the EKC in Tunisia, Morocco, and Egypt during 1980-2014, controlling tourism. They corroborated the EKC in Morocco and Egypt and a Ushaped relationship in Tunisia. Tourism showed a positive impact on emissions in Tunisia and Morocco and showed a negative effect in Egypt. Sulaiman and Abdul-Rahim [74] investigated the EKC in eight African countries' panel, including Egypt, during 1980-2015, controlling biomass energy in analysis. They found the validity of EKC. Moreover, biomass energy usage helped to reduce $\mathrm{CO}_{2}$ emissions. Fethi and Senyucel [31] examined the EKC's control of tourism in analyses of 50 tourist countries. The authors reported the EKC in the panel and most of the investigated countries' time-series analyses. However, the EKC was not validated in Egypt. Moreover, energy consumption had positive and tourism had insignificant impact on emissions. However, both energy use and tourism accelerated emissions in Egypt.

Ignoring the EKC, some literature also investigated the linear relationship between energy and growth in Egypt. For instance, Abdel-Khalek [19] studied and found a positive effect of income on energy consumption, but of a low magnitude. Sharaf [20] performed a causality analysis and found causation between income and oil and electricity usage in Egypt. In addition, the literature has investigated the income and electricity consumption relationship and found that economic growth positively affected electricity consumption in Egypt [23,24].

This literature review has found many studies on EKC testing, but limited studies have investigated the EEKC, which has been tested hypothesizing an inverted U-shaped relationship between energy variables and economic growth [10-13]. Some studies have also considered the possible $\mathrm{N}$-shaped relationship between energy variables and economic growth $[14,15,20-22]$. In the context of Egypt, literature has investigated the EKC in a relationship between pollutant emissions and economic growth [25-31,72,73]. However, the testing of the EEKC is absent in Egyptian literature, which motivates us to investigate $\mathrm{N}$-shaped EEKC in the relationship between different sources of energy consumption and economic growth.

\section{Methods}

Following Luzzati and Orsini [14] and Pablo-Romero and De Jesus [15], we test the isolated $\mathrm{N}$-shaped relationship between absolute energy consumption and GDP per capita in Egypt to verify the EEKC in the following manner:

$$
\mathrm{EC}_{\mathrm{t}}=\mathrm{f}\left(\mathrm{GDPC}_{\mathrm{t}}, \mathrm{GDPC}_{\mathrm{t}}{ }^{2}, \mathrm{GDPC}_{\mathrm{t}}{ }^{3}\right)
$$

$\mathrm{EC}_{\mathrm{t}}$ is the natural logarithm of energy consumption in exajoules, and $\mathrm{GDPC}_{\mathrm{t}}$ is the natural logarithm of GDP per capita in constant Egyptian Pounds. GDPC ${ }_{t}^{2}$ and $\mathrm{GDPC}_{\mathrm{t}}{ }^{3}$ are square and cubic terms of $\mathrm{GDPC}_{t}$ to test the N-shaped EEKC. $t$ is annual time series from 1965 to 2019. Li et al. [21] suggested an inquiry into the different proxies of disaggregated energy consumption in the testing of N-shaped EEKC. Therefore, we test the EEKC with the leading energy sources of Egypt in the following manner:

$$
\begin{gathered}
\mathrm{PEC}_{\mathrm{t}}=\mathrm{f}\left(\mathrm{GDPC}_{\mathrm{t}}, \mathrm{GDPC}_{\mathrm{t}}^{2}, \mathrm{GDPC}_{\mathrm{t}}^{3}\right) \\
\mathrm{OC}_{\mathrm{t}}=\mathrm{f}\left(\mathrm{GDPC}_{\mathrm{t}}, \mathrm{GDPC}_{\mathrm{t}}{ }^{2}, \mathrm{GDPC}_{\mathrm{t}}{ }^{3}\right) \\
\mathrm{NGC}_{\mathrm{t}}=\mathrm{f}\left(\mathrm{GDPC}_{\mathrm{t}}, \mathrm{GDPC}_{\mathrm{t}}{ }^{2}, \mathrm{GDPC}_{\mathrm{t}}{ }^{3}\right) \\
\mathrm{CC}_{\mathrm{t}}=\mathrm{f}\left(\mathrm{GDPC}_{\mathrm{t}}, \mathrm{GDPC}_{\mathrm{t}}{ }^{2}, \mathrm{GDPC}_{\mathrm{t}}{ }^{3}\right)
\end{gathered}
$$




$$
\mathrm{HC}_{\mathrm{t}}=\mathrm{f}\left(\mathrm{GDPC}_{\mathrm{t}}, \mathrm{GDPC}_{\mathrm{t}}^{2}, \mathrm{GDPC}_{\mathrm{t}}^{3}\right)
$$

$\mathrm{PEC}_{\mathrm{t}}, \mathrm{OC}_{\mathrm{t}}, \mathrm{NGC}_{\mathrm{t}}, \mathrm{CC}_{\mathrm{t}}$, and $\mathrm{HC}_{\mathrm{t}}$ are natural logarithms of primary energy, oil, natural gas, coal consumption, and hydroelectricity consumption in exajoules. The data on five proxies of energy consumption are collected from BP [16], and GDP per capita is collected from the World Bank [75].

Before moving to the cointegration analyses, the testing of unit root is a prerequisite. First, we apply the Ng and Perron [76] test, due to its efficiency, in the small-time sample. Then the ARDL of Pesaran et al. [77] is utilized to confirm the long and short-run effects. The models in Equations (2)-(6) are expressed in the ARDL form as follows:

$$
\begin{aligned}
& \Delta \text { PEC }_{\mathrm{t}}=\mathrm{a}_{0}+\mathrm{a}_{11} \mathrm{PEC}_{\mathrm{t}-1}+\mathrm{a}_{12} \mathrm{GDPC}_{\mathrm{t}-1}+\mathrm{a}_{13} \mathrm{GDPC}_{\mathrm{t}-1}^{2}+\mathrm{a}_{14} \mathrm{GDPC}_{\mathrm{t}-1}^{3}+\sum_{\mathrm{i}=1}^{\mathrm{k} 1} \mathrm{a}_{21 \mathrm{i}} \Delta \mathrm{PEC}_{\mathrm{t}-\mathrm{i}} \\
& +\sum_{\mathrm{i}=0}^{\mathrm{k} 2} \mathrm{a}_{22 \mathrm{i}} \Delta \mathrm{GDPC}_{\mathrm{t}-\mathrm{i}}+\sum_{\mathrm{i}=0}^{\mathrm{k} 3} \mathrm{a}_{23 \mathrm{i}} \Delta \mathrm{GDPC}_{\mathrm{t}-\mathrm{i}}^{2}+\sum_{\mathrm{i}=0}^{\mathrm{k} 4} \mathrm{a}_{24 \mathrm{i}} \Delta \mathrm{GDPC}_{\mathrm{t}-\mathrm{i}}^{3}+\mathrm{w}_{1 \mathrm{t}} \\
& \Delta \mathrm{OC}_{\mathrm{t}}=\mathrm{b}_{0}+\mathrm{b}_{11} \mathrm{OC}_{\mathrm{t}-1}+\mathrm{b}_{12} \mathrm{GDPC}_{\mathrm{t}-1}+\mathrm{b}_{13} \mathrm{GDPC}_{\mathrm{t}-1}^{2}+\mathrm{b}_{14} \mathrm{GDPC}_{\mathrm{t}-1}^{3}+\sum_{\mathrm{i}=1}^{11} \mathrm{~b}_{21 \mathrm{i}} \Delta \mathrm{OC}_{\mathrm{t}-\mathrm{i}}+\sum_{\mathrm{i}=0}^{12} \mathrm{~b}_{22 \mathrm{i}} \Delta \mathrm{GDPC}_{\mathrm{t}-\mathrm{i}} \\
& +\sum_{\mathrm{i}=0}^{13} \mathrm{~b}_{23 \mathrm{i}} \Delta \mathrm{GDPC}_{\mathrm{t}-\mathrm{i}}^{2}+\sum_{\mathrm{i}=0}^{14} \mathrm{~b}_{24 \mathrm{i}} \Delta \mathrm{GDPC}_{\mathrm{t}-\mathrm{i}}^{3}+\mathrm{w}_{2 \mathrm{t}} \\
& \Delta \mathrm{NGC}_{\mathrm{t}}=\mathrm{c}_{0}+\mathrm{c}_{11} \mathrm{NGC}_{\mathrm{t}-1}+\mathrm{c}_{12} \mathrm{GDPC}_{\mathrm{t}-1}+\mathrm{c}_{13} \mathrm{GDPC}_{\mathrm{t}-1}^{2}+\mathrm{c}_{14} \mathrm{GDPC}_{\mathrm{t}-1}^{3}+\sum_{\mathrm{i}=1}^{\mathrm{m} 1} \mathrm{c}_{21 \mathrm{i}} \Delta \mathrm{NGC}_{\mathrm{t}-\mathrm{i}} \\
& +\sum_{\mathrm{i}=0}^{\mathrm{m} 2} \mathrm{c}_{22 \mathrm{i}} \Delta \mathrm{GDPC}_{\mathrm{t}-\mathrm{i}}+\sum_{\mathrm{i}=0}^{\mathrm{m} 3} \mathrm{c}_{23 \mathrm{i}} \Delta \mathrm{GDPC}_{\mathrm{t}-\mathrm{i}}^{2}+\sum_{\mathrm{i}=0}^{\mathrm{m} 4} \mathrm{c}_{24 \mathrm{i}} \Delta \mathrm{GDPC}_{\mathrm{t}-\mathrm{i}}^{3}+\omega_{3 \mathrm{t}} \\
& \Delta \mathrm{CC}_{\mathrm{t}}=\mathrm{d}_{0}+\mathrm{d}_{11} \mathrm{CC}_{\mathrm{t}-1}+\mathrm{d}_{12} \mathrm{GDPC}_{\mathrm{t}-1}+\mathrm{d}_{13} \mathrm{GDPC}_{\mathrm{t}-1}^{2}+\mathrm{d}_{14} \mathrm{GDPC}_{\mathrm{t}-1}^{3}+\sum_{\mathrm{i}=1}^{\mathrm{n} 1} \mathrm{~d}_{21 \mathrm{i}} \Delta \mathrm{CC}_{\mathrm{t}-\mathrm{i}} \\
& +\sum_{\mathrm{i}=0}^{\mathrm{n} 2} \mathrm{~d}_{22 \mathrm{i}} \Delta \mathrm{GDPC}_{\mathrm{t}-\mathrm{i}}+\sum_{\mathrm{i}=0}^{\mathrm{n} 3} \mathrm{~d}_{23 \mathrm{i}} \Delta \mathrm{GDPC}_{\mathrm{t}-\mathrm{i}}^{2}+\sum_{\mathrm{i}=0}^{\mathrm{n} 3} \mathrm{~d}_{24 \mathrm{i}} \Delta \mathrm{GDPC}_{\mathrm{t}-\mathrm{i}}^{3}+\mathrm{w}_{4 \mathrm{t}} \\
& \Delta \mathrm{HC}_{\mathrm{t}}=\mathrm{e}_{0}+\mathrm{e}_{11} \mathrm{HC}_{\mathrm{t}-1}+\mathrm{e}_{12} \mathrm{GDPC}_{\mathrm{t}-1}+\mathrm{e}_{13} \mathrm{GDPC}_{\mathrm{t}-1}^{2}+\mathrm{e}_{14} \mathrm{GDPC}_{\mathrm{t}-1}^{3}+\sum_{\mathrm{i}=1}^{\mathrm{o} 1} \mathrm{e}_{21 \mathrm{i}} \Delta \mathrm{HC} \mathrm{t}-\mathrm{i}+\sum_{\mathrm{i}=0}^{\mathrm{o} 2} \mathrm{e}_{22 \mathrm{i}} \Delta \mathrm{GDPC}_{\mathrm{t}-\mathrm{i}} \\
& +\sum_{\mathrm{i}=0}^{\mathrm{o} 3} \mathrm{e}_{23 \mathrm{i}} \Delta \mathrm{GDPC}_{\mathrm{t}-\mathrm{i}}^{2}+\sum_{\mathrm{i}=0}^{\mathrm{o} 4} \mathrm{e}_{24 \mathrm{i}} \Delta \mathrm{GDPC}_{\mathrm{t}-\mathrm{i}}^{3}+\omega_{5 \mathrm{t}}
\end{aligned}
$$

At first, we test the cointegration in Equations (7)-(11) of ARDL models using the bound test. The F-values of Kripfganz and Schneider [78] are utilized, due to their efficiency, in the small-time sample. The statistically significantly positive, negative, and positive parameters of GDP per capita, its square term, and its cubic term, respectively, would confirm the long-run $\mathrm{N}$-curve and EEKC hypothesis in the models of nonrenewable energy consumption in Equations (7)-(10). On the other hand, the opposite parameters would corroborate the EEKC in Equation (11) of the hydroelectricity model, a clean energy consumption source. Hence, the statistically significant negative, positive and negative parameters of GDP, its square term, and its cubic term, respectively, would confirm the long-run inverted N-curve and the EEKC hypothesis in Equation (11). Moreover, the turning points of $\mathrm{N}$-shaped curves may be estimated by the following formulas suggested by Diao et al. [79]:

$$
\begin{aligned}
& \mathrm{GDPC}_{1}=\left(-\mathrm{f}_{2}-\sqrt{\left.\mathrm{f}_{2}^{2}-3 * \mathrm{f}_{1} * \mathrm{f}_{3}\right)} / 3 * \mathrm{f}_{3}\right. \\
& \mathrm{GDPC}_{2}=\left(-\mathrm{f}_{2}+\sqrt{\mathrm{f}_{2}^{2}-3 * \mathrm{f}_{1} * \mathrm{f}_{3}}\right) / 3 * \mathrm{f}_{3}
\end{aligned}
$$

In Equations (12) and (13), $f_{1}, f_{2}$, and $f_{3}$ are the long-run coefficients of GDPC $\mathrm{t}_{\mathrm{t}}, \mathrm{GDPC}_{\mathrm{t}}{ }^{2}$, and $\mathrm{GDPC}_{t}{ }^{3}$. These long-run coefficients are estimated from Equations (7)-(11). Both formulas are applied to each of Equations (7)-(11) individually to find the first turning point at $\mathrm{GDPC}_{1}$ and the second turning point at GDPC $\mathrm{C}_{2}$ in the case of each energy source. Then, we take exponents of estimated $\mathrm{GDPC}_{1}$ and $\mathrm{GDPC}_{2}$ to find the GDP per capita because all data are in the natural logarithm. Figure 3 shows the N-shaped EEKC with turning points at $\mathrm{GDPC}_{1}$ and $\mathrm{GDPC}_{2}$. Before point $\mathrm{GDPC}_{1}$, energy consumption is rising with increasing GDP per capita. After $\mathrm{GDPC}_{1}$, energy consumption is falling with increasing GDP per capita. After $\mathrm{GDPC}_{2}$, energy consumption is growing again with increasing GDP per capita.

$$
\Delta \mathrm{PEC}_{\mathrm{t}}=\mathrm{a}_{31} \mathrm{ECT}_{\mathrm{t}-1}+\sum_{\mathrm{i}=1}^{\mathrm{k} 1} \mathrm{a}_{21 \mathrm{i}} \Delta \mathrm{PEC}_{\mathrm{t}-\mathrm{i}}+\sum_{\mathrm{i}=0}^{\mathrm{k} 2} \mathrm{a}_{22 \mathrm{i}} \Delta \mathrm{GDPC}_{\mathrm{t}-\mathrm{i}}+\sum_{\mathrm{i}=0}^{\mathrm{k} 3} \mathrm{a}_{23 \mathrm{i}} \Delta \mathrm{GDPC}_{\mathrm{t}-\mathrm{i}}^{2}+\sum_{\mathrm{i}=0}^{\mathrm{k} 4} \mathrm{a}_{24 \mathrm{i}} \Delta \mathrm{GDPC}_{\mathrm{t}-\mathrm{i}}^{3}+\partial_{1 \mathrm{t}}
$$




$$
\begin{aligned}
& \Delta \mathrm{OC}_{\mathrm{t}}=\mathrm{b}_{31} \mathrm{ECT}_{\mathrm{t}-1}+\sum_{\mathrm{i}=1}^{11} \mathrm{~b}_{21 \mathrm{i}} \Delta \mathrm{OC}_{\mathrm{t}-\mathrm{i}}+\sum_{\mathrm{i}=0}^{12} \mathrm{~b}_{22 \mathrm{i}} \Delta \mathrm{GDPC}_{\mathrm{t}-\mathrm{i}}+\sum_{\mathrm{i}=0}^{13} \mathrm{~b}_{23 \mathrm{i}} \Delta \mathrm{GDPC}_{\mathrm{t}-\mathrm{i}}^{2}+\sum_{\mathrm{i}=0}^{14} \mathrm{~b}_{24 \mathrm{i}} \Delta \mathrm{GDPC}_{\mathrm{t}-\mathrm{i}}^{3}+\partial_{2 \mathrm{t}} \\
& \Delta \mathrm{NGC}_{\mathrm{t}}=\mathrm{c}_{31} \mathrm{ECT}_{\mathrm{t}-1} \sum_{\mathrm{i}=1}^{\mathrm{m} 1} \mathrm{c}_{21 \mathrm{i}} \Delta \mathrm{NGC}_{\mathrm{t}-\mathrm{i}}+\sum_{\mathrm{i}=0}^{\mathrm{m} 2} \mathrm{c}_{22 \mathrm{i}} \Delta \mathrm{GDPC}_{\mathrm{t}-\mathrm{i}}+\sum_{\mathrm{i}=0}^{\mathrm{m} 3} \mathrm{c}_{23 \mathrm{i}} \Delta \mathrm{GDPC}_{\mathrm{t}-\mathrm{i}}^{2}+\sum_{\mathrm{i}=0}^{\mathrm{m} 4} \mathrm{c}_{24 \mathrm{i}} \Delta \mathrm{GDPC}_{\mathrm{t}-\mathrm{i}}^{3}+\partial_{3 \mathrm{t}} \\
& \Delta \mathrm{CC}_{\mathrm{t}}=\mathrm{d}_{31} \mathrm{ECT}_{\mathrm{t}-1}+\sum_{\mathrm{i}=1}^{\mathrm{n} 1} \mathrm{~d}_{21 \mathrm{i}} \Delta \mathrm{CC}_{\mathrm{t}-\mathrm{i}}+\sum_{\mathrm{i}=0}^{\mathrm{n} 2} \mathrm{~d}_{22 \mathrm{i}} \Delta \mathrm{GDPC}_{\mathrm{t}-\mathrm{i}}+\sum_{\mathrm{i}=0}^{\mathrm{n} 3} \mathrm{~d}_{23 \mathrm{i}} \Delta \mathrm{GDPC}_{\mathrm{t}-\mathrm{i}}^{2}+\sum_{\mathrm{i}=0}^{\mathrm{n} 4} \mathrm{~d}_{24 \mathrm{i}} \Delta \mathrm{GDPC}_{\mathrm{t}-\mathrm{i}}^{3}+\partial_{4 \mathrm{t}} \\
& \Delta \mathrm{HC}_{\mathrm{t}}=\mathrm{e}_{31} \mathrm{ECT}_{\mathrm{t}-1}+\sum_{\mathrm{i}=1}^{\mathrm{o} 1} \mathrm{e}_{21 \mathrm{i}} \Delta \mathrm{HC}_{\mathrm{t}-\mathrm{i}}+\sum_{\mathrm{i}=0}^{\mathrm{o} 2} \mathrm{e}_{22 \mathrm{i}} \Delta \mathrm{GDPC}_{\mathrm{t}-\mathrm{i}}+\sum_{\mathrm{i}=0}^{\mathrm{o} 3} \mathrm{e}_{23 \mathrm{i}} \Delta \mathrm{GDPC}_{\mathrm{t}-\mathrm{i}}^{2}+\sum_{\mathrm{i}=0}^{\mathrm{o}} \mathrm{e}_{24 \mathrm{i}} \Delta \mathrm{GDPC}_{\mathrm{t}-\mathrm{i}}^{3}+\partial_{5 \mathrm{t}}
\end{aligned}
$$

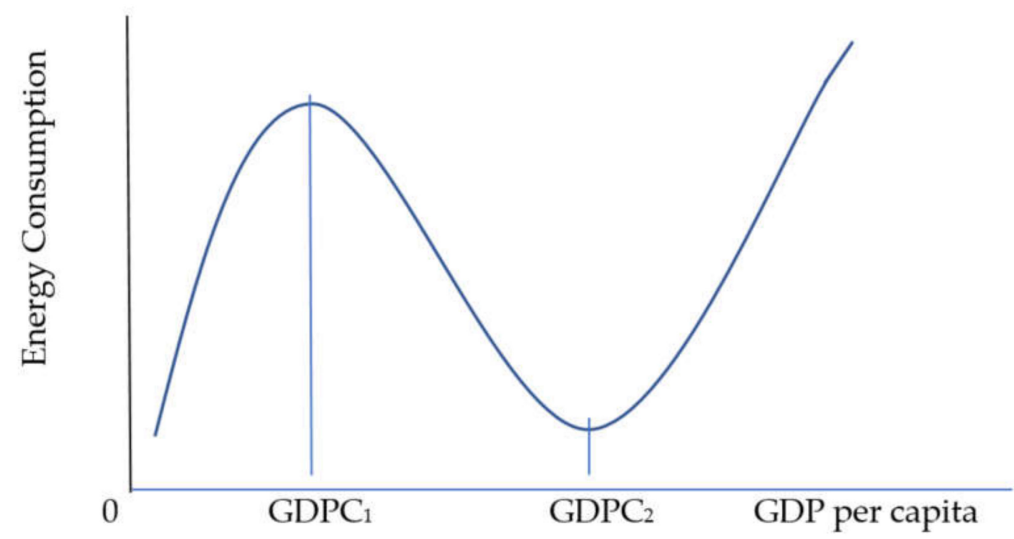

Figure 3. The N-shaped EEKC.

After cointegration analyses, the statistically significant negative parameters of error correction term $\left(\mathrm{ECT}_{\mathrm{t}-1}\right)$ would confirm the short-run relationship in models 14-18 [77]. Then, the short-run EEKC hypothesis may be corroborated with the statistically significant positive, negative, and positive parameters of lag differenced variables of $\mathrm{GDPC}_{\mathrm{t}}$, its square term, and its cubic term, respectively, in models of nonrenewable energy sources in Equations (14)-(17). The opposing statistical evidence can be claimed to confirm the EEKC in the hydroelectricity model in Equation (18).

\section{Results}

Table 1 shows the descriptive statistics of the utilized variable in the EEKC models. All variables are being used in natural logarithm form, as mentioned in Equations (2)-(6). The standard deviation of all variables shows the significant growth of energy consumption variables and GDP per capita.

Table 1. Descriptive Statistics.

\begin{tabular}{ccccccc}
\hline & $\mathbf{O C}_{\mathbf{t}}$ & $\mathbf{N G C}_{\mathbf{t}}$ & $\mathbf{C C}_{\mathbf{t}}$ & $\mathbf{P E C}_{\mathbf{t}}$ & $\mathbf{H C}_{\mathbf{t}}$ & $\mathbf{G D P C}_{\mathbf{t}}$ \\
\hline Mean & -0.224187 & -1.898542 & -3.575728 & 0.244363 & -2.411493 & 9.861380 \\
Median & -0.025270 & -1.078036 & -3.498677 & 0.364126 & -2.281486 & 9.908434 \\
Maximum & 0.567938 & 0.763329 & -2.406410 & 1.365439 & -1.941707 & 10.55649 \\
Minimum & -1.612627 & -6.378393 & -4.467861 & -1.341031 & -4.055660 & 9.082881 \\
Std. Dev. & 0.628077 & 2.467149 & 0.417401 & 0.843266 & 0.510672 & 0.470406 \\
Observations & 55 & 55 & 55 & 55 & 55 & 55 \\
\hline
\end{tabular}

Table 2 exposes the Ng-Perron results. The results show that at this level, $\mathrm{PEC}_{\mathrm{t}}$, $\mathrm{OC}_{\mathrm{t}}, \mathrm{NGC}_{\mathrm{t}}, \mathrm{CC}_{\mathrm{t}}, \mathrm{HC}_{\mathrm{t}}$, and $\mathrm{GDPC}_{\mathrm{t}}$ have unit root, and $\mathrm{GDPC}_{\mathrm{t}}{ }^{2}$ and $\mathrm{GDPC}_{\mathrm{t}}{ }^{3}$ are also nonstationary with intercept in analyses. However, $\mathrm{GDPC}_{t}{ }^{2}$ and $\mathrm{GDPC}_{\mathrm{t}}{ }^{3}$ are level-stationary at $10 \%$ and $5 \%$ significance level, including intercept and trend in analysis. At first differences, 
all variables are stationary. Hence, some evidence of mixed order of integration is found. However, cointegration analyses with this problem can be applied, as ARDL is efficient in the mixed order of integration in the model [73].

Table 2. Unit root results.

\begin{tabular}{|c|c|c|c|c|c|c|c|c|}
\hline \multirow{2}{*}{$\frac{\text { Variable }}{\mathrm{PEC}_{\mathrm{t}}}$} & \multicolumn{4}{|c|}{ Intercept } & \multicolumn{4}{|c|}{ Intercept and Trend } \\
\hline & -4.2658 & -1.2638 & 0.2963 & 6.0270 & -3.9478 & -1.2643 & 0.3203 & 21.4005 \\
\hline $\mathrm{OC}_{\mathrm{t}}$ & 0.5895 & 0.6476 & 1.0985 & 75.7772 & -2.9230 & -1.0404 & 0.3560 & 26.7822 \\
\hline $\mathrm{NGC}_{\mathrm{t}}$ & 0.8080 & 1.0480 & 1.2969 & 107.9720 & -2.3539 & -0.9181 & 0.3900 & 31.7657 \\
\hline $\mathrm{CC}_{\mathrm{t}}$ & -2.6936 & -0.7081 & 0.2629 & 7.7003 & -8.3180 & -1.8994 & 0.2284 & 11.3901 \\
\hline $\mathrm{HC}_{\mathrm{t}}$ & -0.8039 & -0.4699 & 0.5846 & 19.8411 & -5.0146 & -1.4586 & 0.2909 & 17.5758 \\
\hline $\mathrm{GDPC}_{\mathrm{t}}$ & 0.9867 & 0.8374 & 0.8486 & 51.9301 & -9.0978 & -2.0891 & 0.2296 & 10.1875 \\
\hline $\mathrm{GDPC}_{\mathrm{t}}^{2}$ & 1.0413 & 0.8770 & 0.8422 & 51.7753 & $\begin{array}{c}-15.0243 \\
*\end{array}$ & $\begin{array}{c}-2.7179 \\
*\end{array}$ & $\begin{array}{c}0.1809 \\
*\end{array}$ & $\begin{array}{c}6.2016 \\
*\end{array}$ \\
\hline $\mathrm{GDPC}_{\mathrm{t}}{ }^{3}$ & 1.0959 & 0.9141 & 0.8341 & 51.4475 & $-\underset{* *}{18.1113}$ & $\begin{array}{c}-2.9987 \\
* *\end{array}$ & $\underset{* *}{0.1656}$ & $\underset{* *}{5.0958}$ \\
\hline$\triangle \mathrm{PEC}_{\mathrm{t}}$ & $-\underset{* * *}{26.0071}$ & $-\underset{* * *}{3.5823}$ & $\underset{* * *}{0.1377}$ & $\underset{* * *}{1.0198}$ & $-\underset{* * *}{25.9332}$ & $-\underset{* * *}{-3.5905}$ & $\underset{* * *}{0.1385}$ & $\underbrace{3.5789}_{* * *}$ \\
\hline$\Delta \mathrm{OC}_{\mathrm{t}}$ & $-\underset{* * *}{26.4147}$ & $-\underset{* * *}{-3.6155}$ & $\underset{* * *}{0.1369}$ & $\underset{* * *}{0.9885}$ & $-\underset{* * *}{26.2858}$ & $-\underset{* * *}{-3.6236}$ & $\underset{* * *}{0.1379}$ & $\underset{* * *}{3.4769}$ \\
\hline$\Delta \mathrm{NGC}_{\mathrm{t}}$ & $-\underset{* * *}{-35.7491}$ & $\underset{* * *}{-4.2218}$ & $\underset{* * *}{0.1181}$ & $\underset{* * *}{0.7030}$ & $-\underset{* * *}{140.6270}$ & $-\underset{* * *}{-8.3848}$ & $\underset{* * *}{0.0596}$ & $\underset{* * *}{0.6496}$ \\
\hline$\Delta \mathrm{CC}_{\mathrm{t}}$ & -4.3428 & -1.4666 & 0.3376 & 5.6538 & $-\underset{* * *}{25.7829}$ & $\underset{* * *}{-3.5668}$ & $\underset{* * *}{0.1383}$ & $\underset{* * *}{3.6748}$ \\
\hline$\Delta \mathrm{HC}_{\mathrm{t}}$ & $-\underset{* * *}{-16.7487}$ & $\underset{* * *}{-2.8835}$ & $\underset{* * *}{0.1722}$ & $\underset{* * *}{1.5016}$ & $\underset{* *}{-20.2622}$ & $\underset{* *}{-3.1806}$ & $\underset{* *}{0.1569}$ & $\underset{* *}{4.5127}$ \\
\hline$\Delta \mathrm{GDPC}_{\mathrm{t}}$ & $-\underset{* * *}{24.3503}$ & $-\underset{* * *}{-3.4847}$ & $\underset{* * *}{0.143} 1$ & $\underset{* * *}{1.0217}$ & $-\underset{* * *}{24.3679}$ & $-\underset{* * *}{-3.4874}$ & $\underset{* * *}{0.1431}$ & $\underset{* * *}{3.7588}$ \\
\hline$\Delta \mathrm{GDPC}_{\mathrm{t}}{ }^{2}$ & $-\underset{* * *}{25.9124}$ & $-\underset{* * *}{-3.5908}$ & $\underset{* * *}{0.1389}$ & $\underset{* * *}{0.9739}$ & $-\underset{* * *}{25.6068}$ & $-\underset{* * *}{-3.5743}$ & $\underset{* * *}{0.1396}$ & $\underset{* * *}{3.5819}$ \\
\hline$\Delta \mathrm{GDPC}_{\mathrm{t}}{ }^{3}$ & $-\underset{* * *}{27.5211}$ & $-\underset{* * *}{-3.6954}$ & $\underset{* * *}{0.1343}$ & $\underset{* * *}{0.1343}$ & $-\underset{* * *}{27.1362}$ & $-\underset{* * *}{-3.6787}$ & $\underset{* * *}{0.1356}$ & $\underbrace{3.3862}_{* * *}$ \\
\hline
\end{tabular}

Note: ${ }^{* * *},{ }^{* *}$ and ${ }^{*}$ show stationarity at $1 \%, 5 \%$, and $10 \%$ significant levels.

Table 3 displays the bound test results of models mentioned in Equations (7)-(11). Results show that the cointegration is found in the models of $\mathrm{PEC}_{\mathrm{t}}, \mathrm{OC}_{\mathrm{t}}, \mathrm{NGC}_{\mathrm{t}}$, and $\mathrm{HC}_{\mathrm{t}}$ at a $1 \%$ level of significance. The bound test could not validate the cointegration in the $\mathrm{CC}_{\mathrm{t}}$ model. However, the cointegration in the $\mathrm{CC}_{\mathrm{t}}$ model is alternatively corroborated with estimated negative parameters of $\mathrm{ECT}_{\mathrm{t}-1}$ in Table 4 [77]. Moreover, diagnostic tests of all estimated models confirm the robustness of the estimated results.

Table 4 shows the estimated parameters of models in Equations (7)-(11). In the long run, the coefficients of $\mathrm{LGDPC}_{t}, \mathrm{LGDPC}_{t}{ }^{2}$, and $\mathrm{LGDPC}_{t}{ }^{3}$ are positive, negative, and positive, respectively, in primary energy, oil, and coal consumption models. Hence, the longrun EEKC hypothesis is corroborated in the N-shaped estimations of these energy proxies. Onafowora and Owoye [72] found an N-shaped relationship between pollutant emissions and economic growth and validated the EKC in the case of Egypt. However, this present study contributes to the literature by providing new evidence of the N-shaped EEKC in the relationship between economic growth and primary energy, oil, and coal consumption. Now, we can calculate the turning points, $\mathrm{GPDC}_{1}$ and $\mathrm{GDPC}_{2}$, of the N-shaped curve from the formulas mentioned in Equations (12) and (13). In the case of primary and oil consumption models, the square root terms' results are complex numbers in Equations (12) and (13), which are $\sqrt{f_{2}^{2}-3 * f_{1} * f_{3}}=\sqrt{-1.6972}$ and $\sqrt{f_{2}^{2}-3 * f_{1} * f_{3}}=\sqrt{-1.3769}$. Hence, the calculations of turning points are not possible due to the square roots of negative numbers. However, the negative values are too small and would not significantly affect the final outcome of the rest of the formula, mentioned in Equations (12) and (13). If we ignore the square root portion of Equations (12) and (13) with an assumption, then the 
turning points are approximately located at 23,787 and 25,044 constant Egyptian pounds GDP per capita for primary energy and oil consumption models, which were in 1998 and 2000. Hence, both models show that primary energy and oil consumptions decline negligibly during 1998 and 2000 and continuously rise in the rest of the sample period. We have observed from Figure 1 that oil consumption was more than $50 \%$ of total energy consumption until 2001. Hence, total energy (primary energy) and oil consumption rise due to economic growth in most of the sample period. In the coal consumption model, we calculate $\mathrm{GDPC}_{1}=13,347$ and $\mathrm{GDPC}_{2}=27,144$ from Equations (12) and (13). Hence, $\mathrm{GDPC}_{1}$ is found in 1979 , and $\mathrm{GDPC}_{2}$ is found in 2005 . Hence, economic growth helps to reduce coal consumption during 1979-2005, and accelerates coal consumption in the sample periods 1965-1978 and 2006-2019. Hence, economic growth in recent years is responsible for increasing nonrenewable energy consumption. Therefore, it seems pertinent to float the idea that national policies discourage the consumption of non-renewables. Particularly, these policies should also be suggested at the regional level by territorial governments to discourage urban energy consumption, which might carry a significant proportion of national energy consumption. These policies have also been recommended by the past literature [80,81]. Moreover, all parameters of $\mathrm{LGDPC}_{t}, \mathrm{LGDPC}_{t}{ }^{2}$, and $\mathrm{LGDPC}_{t}{ }^{3}$ are statistically insignificant in the case of natural gas and hydroelectricity consumption. Therefore, the EEKC hypothesis is not corroborated in natural gas and hydroelectricity consumption models. Moreover, none of the monotonic, quadratic, or cubic effects of economic growth on natural consumption and hydroelectricity consumptions could be validated. This conclusion of the non-existence of EEKC is in line with the results of other EKC studies conducted in Egypt, which could not establish any inverted U-shaped or $\mathrm{N}$-shaped relationship between economic growth and pollution emissions [25,28,31,73].

Table 5 shows the estimated short-run coefficients of models in Equations (14)-(18). The short-run relationships are corroborated in all estimated models with the negative and statistically significant parameters of $\mathrm{ECT}_{\mathrm{t}-1}$ in Equations (14)-(18). Moreover, the coefficients of $\triangle \mathrm{LGDPC}_{\mathrm{t}}, \Delta \mathrm{LGDPC}_{\mathrm{t}}{ }^{2}$, and $\triangle \mathrm{LGDPC}_{\mathrm{t}}{ }^{3}$ are found to be positive, negative, and positive, respectively, in the models of primary energy, oil, and coal consumptions. Hence, the short-run EEKC hypothesis is corroborated in the N-shaped relationship of growth and energy consumption in the case of oil, coal, and primary energy consumption. In the case of natural gas consumption, parameters of $\Delta \mathrm{LGDPC}, \Delta \mathrm{LGDPC}_{\mathrm{t}}{ }^{2}$, and $\Delta \mathrm{LGDPC}_{\mathrm{t}}{ }^{3}$ are found to be positive, negative, and statistically insignificant, respectively. Hence, an inverted Ucurve EEKC is verified in the natural gas consumption model. The inverted U-shaped EKC in a relationship between pollution emissions and economic growth has been reported by existing studies when conducting time series analysis in Egypt $[26,27,30]$ and performing panel data analysis, including in Egypt [74]. In the hydroelectricity consumption model, an inverted $\mathrm{N}$-shaped relationship is corroborated with negative, positive, and negative parameters of $\triangle \mathrm{LGDPC}_{\mathrm{t}}, \Delta \mathrm{LGDPC}_{\mathrm{t}}{ }^{2}$, and $\Delta \mathrm{LGDPC}_{\mathrm{t}}{ }^{3}$, respectively. Hence, hydroelectricity consumption decreases at the first stage of economic growth, increases at the second stage, and reduces at the third stage. This finding is in line with the finding of an N-shaped relationship between pollution emissions and economic growth in Egypt [72]. We may compare our findings with those of Onafowora and Owoye [72] in that increasing economic growth at the first stage increases pollution, which shows a shift from hydroelectricity or any other renewable to nonrenewable sources of energy. In the second stage, economic growth helps to reduce emissions, which provides evidence of a shift from nonrenewable to renewable sources of energy. In the third stage, emissions increase with economic growth, which again shows a shift from renewable to nonrenewable sources. Hence, the short-run EEKC is verified as hydroelectricity consumption is a renewable energy source. On the whole, the short-run EEKC is validated in the case of all estimated models.

In summary, the long run EEKC is corroborated in primary energy, oil, and coal consumption in Egypt. Hence, economic growth is responsible for increasing oil, coal, and primary energy consumption in most sample years, all nonrenewable. Therefore, increasing such energy consumption types is responsible for environmental degradation. On the 
other hand, economic growth could not help to increase hydroelectricity consumption. Moreover, the short-run EEKC is confirmed in all the investigated models. Though the present study did not include the effects of globalization and economic openness on energy consumption behavior, the literature has highlighted the role of trade in shaping the EKC in a relationship between pollutant emissions and economic growth $[1,36]$. Furthermore, the previous environmental literature has corroborated that trade and FDI have helped to reduce pollutant emissions in Egypt [25,26]. Hence, the openness of the economy has contributed to shaping of the EKC in Egypt.

Table 3. Bound testing.

\begin{tabular}{|c|c|c|c|c|c|}
\hline Model & F-Stat. & Hetero. & Serial Correlation & Normality & Functional Form \\
\hline $\mathrm{PEC}_{\mathrm{t}}$ & 4.6340 & $\begin{array}{c}0.9459 \\
(0.3354)\end{array}$ & $\begin{array}{c}1.6229 \\
(0.2087)\end{array}$ & $\begin{array}{l}26.5508 \\
(0.0000)\end{array}$ & $\begin{array}{c}2.3367 \\
(0.1341)\end{array}$ \\
\hline $\mathrm{OC}_{\mathrm{t}}$ & 7.7437 & $\begin{array}{c}2.0329 \\
(0.1600)\end{array}$ & $\begin{array}{c}1.8552 \\
(0.1795)\end{array}$ & $\begin{array}{c}34.215 \\
(0.0000)\end{array}$ & $\begin{array}{c}1.9615 \\
(0.1520)\end{array}$ \\
\hline $\mathrm{NGC}_{\mathrm{t}}$ & 7.5839 & $\begin{array}{l}16.1084 \\
(0.0000)\end{array}$ & $\begin{array}{c}1.3060 \\
(0.2806)\end{array}$ & $\begin{array}{l}106.3483 \\
(0.0000)\end{array}$ & $\begin{array}{c}0.0027 \\
(0.9589)\end{array}$ \\
\hline $\mathrm{CC}_{\mathrm{t}}$ & 1.7022 & $\begin{array}{c}1.0385 \\
(0.3130)\end{array}$ & $\begin{array}{c}0.6389 \\
(0.4282)\end{array}$ & $\begin{array}{c}1.4937 \\
(0.4739)\end{array}$ & $\begin{array}{c}0.1413 \\
(0.7088)\end{array}$ \\
\hline $\mathrm{HC}_{\mathrm{t}}$ & 7.0509 & $\begin{array}{c}0.5800 \\
(0.5637)\end{array}$ & $\begin{array}{c}0.6694 \\
(0.5174)\end{array}$ & $\begin{array}{c}8.8042 \\
(0.0123)\end{array}$ & $\begin{array}{c}2.5999 \\
(0.1142)\end{array}$ \\
\hline \multicolumn{6}{|c|}{ Critical F-statistics } \\
\hline At 1 percent & & & $4.0934-4.9199$ & & \\
\hline At 5 percent & & & $3.0836-3.8155$ & & \\
\hline At 10 percent & & & $2.6175-3.2969$ & & \\
\hline
\end{tabular}

Table 4. Long run results.

\begin{tabular}{|c|c|c|c|c|c|}
\hline Dependent Variable & Independent Variable & Coefficient & Std. Error & $t$-Statistic & Prob. \\
\hline \multirow[t]{4}{*}{$\mathrm{PEC}_{\mathrm{t}}$} & $\mathrm{LGDPC}_{\mathrm{t}}$ & 112.0502 & 47.7788 & 2.3452 & 0.0233 \\
\hline & LGDPC $_{t}^{2}$ & -10.9647 & 4.8552 & -2.2584 & 0.0286 \\
\hline & LGDPC $_{t}{ }^{3}$ & 0.3627 & 0.1642 & 2.2083 & 0.0321 \\
\hline & Intercept & -386.1950 & 156.5130 & -2.4675 & 0.0173 \\
\hline \multirow[t]{4}{*}{$\mathrm{OC}_{\mathrm{t}}$} & LGDPC $_{t}$ & 188.7147 & 88.1676 & 2.1404 & 0.0373 \\
\hline & $\mathrm{LGDPC}_{\mathrm{t}}{ }^{2}$ & -18.4347 & 8.9762 & -2.0537 & 0.0454 \\
\hline & LGDPC $_{t}^{3}$ & 0.6027 & 0.3042 & 1.9812 & 0.0532 \\
\hline & Intercept & -646.3510 & 288.2987 & -2.2420 & 0.0295 \\
\hline \multirow[t]{4}{*}{$\mathrm{NGC}_{\mathrm{t}}$} & LGDPC $_{t}$ & 317.8377 & 221.3655 & 1.4358 & 0.1574 \\
\hline & LGDPC $_{t}^{2}$ & -29.1443 & 22.3645 & -1.3032 & 0.1986 \\
\hline & $\mathrm{LGDPC}_{\mathrm{t}}{ }^{3}$ & 0.8958 & 0.7521 & 1.1909 & 0.2394 \\
\hline & Intercept & -1160.3700 & 729.3086 & -1.5911 & 0.1180 \\
\hline \multirow[t]{4}{*}{$\mathrm{CC}_{\mathrm{t}}$} & $\mathrm{LGDPC}_{\mathrm{t}}$ & 1700.2550 & 1005.4270 & 1.6911 & 0.0974 \\
\hline & LGDPC $_{t}{ }^{2}$ & -172.7690 & 102.4808 & -1.6859 & 0.0985 \\
\hline & LGDPC $_{t}^{3}$ & 5.8443 & 3.4770 & 1.6808 & 0.0994 \\
\hline & Intercept & -5573.6000 & 3283.2480 & -1.69759 & 0.0962 \\
\hline \multirow[t]{4}{*}{$\mathrm{HC}_{\mathrm{t}}$} & LGDPC $_{t}$ & -430.89 & 442.13 & -0.9746 & 0.3351 \\
\hline & LGDPC $_{t}{ }^{2}$ & 43.2323 & 44.5783 & 0.9698 & 0.3374 \\
\hline & LGDPC $_{t}{ }^{3}$ & -1.4422 & 1.4968 & -0.9635 & 0.3406 \\
\hline & Intercept & 1425.3810 & 1460.2370 & 0.9761 & 0.3343 \\
\hline
\end{tabular}


Table 5. Short run results.

\begin{tabular}{|c|c|c|c|c|c|}
\hline Dependent Variable & Independent Variable & Coefficient & Std. Error & t-Statistic & Prob. \\
\hline \multirow[t]{5}{*}{$\triangle \mathrm{PEC}_{\mathrm{t}}$} & $\Delta \mathrm{PEC}_{\mathrm{t}-1}$ & -0.2232 & 0.1081 & -2.0641 & 0.0445 \\
\hline & $\Delta$ LGDPC $_{\mathrm{t}}$ & 88.5923 & 32.5737 & 2.7198 & 0.0091 \\
\hline & $\Delta \mathrm{LGDPC}_{\mathrm{t}}^{2}$ & -8.6692 & 3.3243 & -2.6079 & 0.0122 \\
\hline & $\Delta \mathrm{LGDPC}_{\mathrm{t}}{ }^{3}$ & 0.2868 & 0.1128 & 2.5421 & 0.0144 \\
\hline & $\mathrm{ECT}_{\mathrm{t}-1}$ & -0.7907 & 0.1274 & -6.2055 & 0.0000 \\
\hline \multirow[t]{4}{*}{$\Delta \mathrm{OC}_{\mathrm{t}}$} & $\Delta$ LGDPC $_{t}$ & 104.8086 & 44.8486 & 2.3369 & 0.0236 \\
\hline & $\Delta \mathrm{LGDPC}_{\mathrm{t}}^{2}$ & -10.2383 & 4.5717 & -2.2395 & 0.0297 \\
\hline & $\Delta \mathrm{LGDPC}_{\mathrm{t}}{ }^{3}$ & 0.3348 & 0.1552 & 2.1572 & 0.0359 \\
\hline & $\mathrm{ECT}_{\mathrm{t}-1}$ & -0.5554 & 0.1067 & -5.2033 & 0.0000 \\
\hline \multirow[t]{4}{*}{$\Delta \mathrm{NGC}_{\mathrm{t}}$} & $\Delta \mathrm{LGDPC}_{\mathrm{t}}$ & 215.6292 & 111.8583 & 1.9277 & 0.0597 \\
\hline & $\Delta \mathrm{LGDPC}_{\mathrm{t}}^{2}$ & -19.7723 & 11.4202 & -1.7313 & 0.0897 \\
\hline & $\Delta \mathrm{LGDPC}_{\mathrm{t}}{ }^{3}$ & 0.6077 & 0.3892 & 1.5614 & 0.1249 \\
\hline & $\mathrm{ECT}_{\mathrm{t}-1}$ & -0.6784 & 0.2956 & -2.2951 & 0.0260 \\
\hline \multirow[t]{4}{*}{$\Delta C_{t}$} & $\Delta$ LGDPC $_{\mathrm{t}}$ & 389.3343 & 173.3717 & 2.2457 & 0.0295 \\
\hline & $\Delta \mathrm{LGDPC}_{\mathrm{t}}^{2}$ & -42.3082 & 18.3057 & -2.3112 & 0.0253 \\
\hline & $\Delta \mathrm{LGDPC}_{\mathrm{t}}{ }^{3}$ & 1.5236 & 0.6453 & 2.3610 & 0.0224 \\
\hline & $\mathrm{ECT}_{\mathrm{t}-1}$ & -0.2290 & 0.1140 & -2.0091 & 0.0503 \\
\hline \multirow[t]{5}{*}{$\Delta \mathrm{HC}_{\mathrm{t}}$} & $\Delta \mathrm{HC}_{\mathrm{t}-1}$ & 0.3983 & 0.1356 & 2.9378 & 0.0052 \\
\hline & $\Delta$ LGDPC $_{\mathrm{t}}$ & -535.0280 & 233.1376 & -2.2949 & 0.0266 \\
\hline & $\Delta \mathrm{LGDPC}_{\mathrm{t}}{ }^{2}$ & 54.6496 & 23.8973 & 2.2869 & 0.0271 \\
\hline & $\Delta \mathrm{LGDPC}_{\mathrm{t}}{ }^{3}$ & -1.8540 & 0.8150 & -2.2748 & 0.0278 \\
\hline & $\mathrm{ECT}_{\mathrm{t}-1}$ & -0.1319 & 0.0548 & -2.4068 & 0.0204 \\
\hline
\end{tabular}

\section{Conclusions}

The testing of the EKC between economic growth and pollutant emissions is abundant in the environmental literature. Nevertheless, EEKC hypothesis testing in the relationship between energy use and economic growth is limited globally and has not been conducted in Egyptian literature. Hence, we investigated the EEKC in the N-shaped relationship between growth and different renewable and nonrenewable proxies of energy consumption in Egypt from 1965-2019. For this purpose, we apply the ARDL cointegration technique. The long-run results corroborate the N-curve in the case of primary energy consumption, oil consumption, and coal consumption models. Hence, the long-run EEKC is verified in these energy consumption proxies. Both oil and primary consumption reduced negligibly in 1998 and 2000 and had a positive relationship with economic growth in the rest of the sample period. Hence, primary energy and oil consumption increase along with economic growth in most of the sample period. However, we calculated both turning points of the $\mathrm{N}$-curve between coal consumption and economic growth. We found the first turning point at 13,347 and the second at 27,144 located at years 1979 and 2005, respectively. Therefore, the economic growth reduced the coal consumption during 1979-2005 and is responsible for increasing coal consumption in the rest of the sample periods 1965-1978 and 2006-2019. On the other hand, the long-run EEKC is invalid in the case of hydroelectricity and natural gas consumption. Hence, economic growth in Egypt has environmental consequences in most of the sample period. We find the N-shaped relationship in primary energy, oil, and coal consumption models in the short-run results. In addition, we find a short-run inverted U-curve in the natural gas consumption model. Moreover, a short-run inverted $\mathrm{N}$-curve is corroborated in hydroelectricity, which is a clean energy source. Hence, the short-run EEKC has been found in all investigated energy sources. Previous literature has incorporated and corroborated the role of the openness of the economy in shaping the EKC in the relationship between pollutant emissions and economic growth in Egypt $[25,26]$. Hence, a future study may consider the role of free trade and other open measures in the relationship between economic growth and energy consumption when investigating the EEKC. 
Author Contributions: Conceptualization, T.T.Y.A. and H.M.; methodology, H.M.; software, H.M.; validation, T.T.Y.A.; formal analysis, H.M.; investigation, T.T.Y.A.; data curation, M.T. and D.H.I.M.; writing—original draft preparation, T.T.Y.A.; writing—review and editing, H.M., D.H.I.M. and M.T.; visualization, T.T.Y.A.; supervision, T.T.Y.A.; project administration, T.T.Y.A.; funding acquisition, M.T. All authors have read and agreed to the published version of the manuscript.

Funding: This research received no external funding.

Institutional Review Board Statement: Not applicable.

Informed Consent Statement: Not applicable.

Data Availability Statement: The data are publicly available [15,58].

Acknowledgments: All authors would like to thank Prince Sultan University for supporting Article Processing Charges to publish in the International Journal of Environmental Research and Public Health.

Conflicts of Interest: The authors declare no conflict of interest.

\section{References}

1. Grossman, G.M.; Krueger, A.B. Environmental Impacts of the North American Free Trade Agreement; NBER, Working Paper 3914. 1991. Available online: https:/ / www.nber.org/papers/w3914 (accessed on 15 March 2021).

2. Panayotou, T. Empirical Tests and Policy Analysis of Environmental Degradation at Different Stages of Economic Development; ILO, Technology and Employment Programme: Geneva, Switzerland, 1993.

3. Kuznets, S. Economic growth and income inequality. Am. Econ. Rev. 1955, 45, 1-28.

4. Mahmood, H.; Maalel, N.; Hassan, M.S. Probing the Energy-Environmental Kuznets Curve Hypothesis in the Oil and Natural Gas Consumption models Considering Urbanization and Financial Development in the Middle East Countries. Energies 2021, 14, 3178. [CrossRef]

5. Simionescu, M.; Păuna, C.B.; Niculescu, M.-D.V. The Relationship between Economic Growth and Pollution in Some New European Union Member States: A Dynamic Panel ARDL Approach. Energies 2021, 14, 2363. [CrossRef]

6. Alola, A.A.; Donve, U.T. Environmental Implication of Coal and Oil Energy Utilization in Turkey: Is the EKC Hypothesis related to Energy? Manag. Environ. Qual. 2021, 32, 543-559. [CrossRef]

7. Chang, D.S.; Yeh, L.T.; Chen, Y. The Effects of Economic Development, International Trade, Industrial Structure and Energy Demands on Sustainable Development. Sustain. Dev. 2014, 22, 377-390. [CrossRef]

8. Zarzoso, I.M.; Motrancho, A.B. Pooled Mean Group Estimation of an Environmental Kuznets Curve for CO 2 . Econ. Lett. 2004, 82, 121-126. [CrossRef]

9. Mahmood, H.; Alrasheed, A.S.; Furqan, M. Financial Market Development and Pollution Nexus in Saudi Arabia: Asymmetrical Analysis. Energies 2018, 11, 3462. [CrossRef]

10. Suri, V.; Chapman, D. Economic Growth, Trade and Energy: Implications for the Environmental Kuznets Curve. Ecol. Econ. 1998, 25, 195-208. [CrossRef]

11. Aruga, K. Investigating the Energy-Environmental Kuznets Curve Hypothesis for the Asia-Pacific Region. Sustainability 2019, 11, 2395. [CrossRef]

12. Hundie, S.K.; Daksa, M.D. Does Energy-Environmental Kuznets Curve Hold for Ethiopia? The Relationship between Energy Intensity and Economic Growth. J. Econ. Struct. 2019, 8, 21. [CrossRef]

13. Aboagye, S. The Policy Implications of the Relationship between Energy Consumption, Energy Intensity and Economic Growth in Ghana. OPEC Energy Rev. 2017, 41, 344-363. [CrossRef]

14. Luzzati, T.; Orsini, M. Investigating the Energy-Environmental Kuznets Curve. Energy 2009, 34, 291-300. [CrossRef]

15. Pablo-Romero, M.D.P.; De Jesus, J. Economic Growth and Energy Consumption: The Energy-Environmental Kuznets Curve for Latin America and the Caribbean. Renew. Sustain. Energy Rev. 2016, 60, 1343-1350. [CrossRef]

16. BP. BP Statistical Review of World Energy. 2021. Available online: https://www.bp.com/statisticalreview (accessed on 21 March 2021).

17. National Energy Technology Laboratory. Cost and Performance Baseline for Fossil Energy Plants; United States Department of Energy No. DOE/NETL-2010/1397; National Energy Technology Laboratory: Morgantown, WV, USA, 2010.

18. Park, S. American Security Project (ASP)'s Report on Energy in Egypt: Background and Issues. 2015. Available online: https: //www.americansecurityproject.org/wp-content/uploads/2015/03/Ref-0190-Energy-in-Egypt-Background-and-Issues.pdf (accessed on 15 April 2021).

19. Abdel-Khalek, G. Income and price elasticities of energy consumption in Egypt: A time-series analysis. Energy Econ. 1988, 10, 47-58. [CrossRef]

20. Sharaf, M.F. Energy consumption and economic growth: A disaggregated causality analysis with structural breaks. Reg. Dev. 2017, 46, 59-76. 
21. Li, S.; Shi, J.; Wu, Q. Environmental Kuznets Curve: Empirical Relationship between Energy Consumption and Economic Growth in Upper-Middle-Income Regions of China. Int. J. Environ. Res. Public Health 2020, 17, 6971. [CrossRef] [PubMed]

22. Ge, X.; Zhou, Z.; Zhou, Y.; Ye, X.; Liu, S. A Spatial Panel Data Analysis of Economic Growth, Urbanization, and NOx Emissions in China. Int. J. Environ. Res. Public Health 2018, 15, 725. [CrossRef]

23. Ibrahiem, D.M. Renewable electricity consumption, foreign direct investment and economic growth in Egypt: An ARDL approach. Procedia Econ. Financ. 2015, 30, 313-323. [CrossRef]

24. Kwakwa, P.A. Electricity consumption in Egypt: A long-run analysis of its determinants. OPEC Energy Rev. 2017, 41, 3-22. [CrossRef]

25. Ibrahiem, D.M. Environmental Kuznets curve: An empirical analysis for carbon dioxide emissions in Egypt. Int. J. Green Econ. 2016, 10, 136-150. [CrossRef]

26. Mahmood, H.; Furqan, M.; Alkhateeb, T.T.Y.; Fawaz, M.M. Testing the environmental Kuznets curve in Egypt: Role of foreign investment and trade. Int. J. Energy Econ. Policy 2019, 9, 225-228.

27. El-Aasar, K.M.; Hanafy, S.A. Investigating the environmental Kuznets curve hypothesis in Egypt: The role of renewable energy and trade in mitigating GHGs. Int. J. Energy Econ. Policy 2018, 8, 177-184.

28. Beşe, E.; Kalayci, S. Testing the environmental Kuznets curve hypothesis: Evidence from Egypt, Kenya and Turkey. Int. J. Energy Econ. Policy 2019, 9, 479-491. [CrossRef]

29. Moosa, I.A. Growth and environmental degradation in MENA countries: Methodological issues and empirical evidence. Middle East Dev. J. 2019, 11, 251-269. [CrossRef]

30. Sghaier, A.; Guizani, A.; Ben Jabeur, S.; Nurunnabi, M. Tourism development, energy consumption and environmental quality in Tunisia, Egypt and Morocco: A trivariate analysis. GeoJournal 2019, 84, 593-609. [CrossRef]

31. Fethi, S.; Senyucel, E. The role of tourism development on $\mathrm{CO}_{2}$ emission reduction in an extended version of the environmental Kuznets curve: Evidence from top 50 tourist destination countries. Environ. Dev. Sustain. 2021, 23, 1499-1524. [CrossRef]

32. Copeland, B.R.; Taylor, M.S. Trade and environment: A partial synthesis. Am. J. Agric. Econ. 1995, 77, 765-771. [CrossRef]

33. Hettige, H.; Lucas, R.E.B.; Wheeler, D. The toxic intensity of industrial production: Global patterns, trends, and trade policy. Am. Econ. Rev. 1992, 82, 478-481.

34. Saint-Paul, G. Chapter 2. In The Economics of Sustainable Development; Goldin, I., Winter, A.L., Eds.; Cambridge University Press: Cambridge, UK, 1994; pp. 47-50.

35. Rock, M.T. Pollution intensity of GDP and trade policy: Can the World Bank be wrong. World Dev. 1996, 24, 471-479. [CrossRef]

36. Grossman, G.M.; Krueger, A.B. Economic growth and the environment. Q. J. Econ. 1995, 110, 353-377. [CrossRef]

37. Antweiler, W.; Copeland, B.R.; Taylor, M.S. Is free trade good for the environment? Am. Econ. Rev. 2001, 91, 877-908. [CrossRef]

38. Arrow, K.; Bolin, B.; Costanza, R.; Folke, C.; Holling, C.S.; Janson, B.; Levin, S.; Maler, K.; Perrings, C.; Pimental, D. Economic growth, carrying capacity, and the environment. Science 1995, 15, 91-95.

39. Coondoo, D.; Dinda, S. Causality between income and emission: A country group-specific econometric analysis. Ecol. Econ. 2002, 40, 351-367. [CrossRef]

40. Lucas, R.E.B.; Wheeler, D.; Hettige, H. Economic Development, Environmental Regulation and the International Migration of Toxic Industrial Pollution: 1960-1988; International Trade and the Environment. World Bank Discussion Paper No. 159; World Bank: Washington, DC, USA, 1992.

41. Stern, D.I. The Rise and Fall of the Environmental Kuznets Curve. World Dev. 2004, 32, 1419-1439. [CrossRef]

42. Stern, D.I.; Common, M.S. Is there an environmental Kuznets curve for sulfur? J. Environ. Econ. Manag. 2001, 41, 162-217. [CrossRef]

43. Millimet, D.L.; List, J.A.; Stengos, T. The environmental Kuznets curve: Real progress or misspecified models? Rev. Econ. Stat. 2003, 85, 1038-1047. [CrossRef]

44. Akkemike, K.A.; Göksal, K. Energy Consumption-GDP Nexus: Heterogeneous panel causality analysis. Energy Econ. 2012, 34, 865-873. [CrossRef]

45. Payne, J.E. On the dynamics of energy consumption and output in the US. Appl. Energy 2009, 86, 575-577. [CrossRef]

46. Ouedraogo, N.S. Energy consumption and economic growth: Evidence from the economic community of West African states (ECOWAS). Energy Econ. 2013, 36, 637-647. [CrossRef]

47. Huang, B.; Hwang, M.; Yang, C.W. 2008. Causal relationship between energy consumption and GDP growth revisited: A dynamic panel data approach. Ecol. Econ. 2008, 67, 41-54. [CrossRef]

48. Shahbaz, M.; Lean, H.H.; Shabbir, M.S. Environmental Kuznets Curve Hypothesis in Pakistan: Cointegration and Granger Causality. Renew. Sustain. Energy Rev. 2012, 16, 2947-2953. [CrossRef]

49. Nasir, M.; Rehman, F.U. Environmental Kuznets Curve for Carbon Emissions in Pakistan: An Empirical Investigation. Energy Policy 2011, 39, 1857-1864. [CrossRef]

50. Shahbaz, M.; Mallick, H.; Mahalik, M.K.; Loganathan, N. Does globalization Impede Environmental Quality in India? Ecol. Indic. 2015, 52, 379-393. [CrossRef]

51. Bayer, C.; Hanck, C. Combining Non-Cointegration Tests. J. Time Ser. Anal. 2013, 34, 83-95. [CrossRef]

52. Jalil, A.; Mahmud, S.F. Environment Kuznets Curve for $\mathrm{CO}_{2}$ Emissions: A Cointegration Analysis for China. Energy Policy 2009, 37, 5167-5172. [CrossRef] 
53. Shahbaz, M.; Haouas, I.; Sohag, K.; Ozturk, I. The Financial Development-Environmental Degradation Nexus in the United Arab Emirates: The Importance of Growth, Globalization and Structural Breaks. Environ. Sci. Pollut. Res. 2020, 27, 10685-10699. [CrossRef]

54. Ozturk, I.; Acaravci, A. The Long-Run and Causal Analysis of Energy, growth, Openness and Financial Development on Carbon Emissions in Turkey. Energy Econ. 2013, 36, 262-267. [CrossRef]

55. Shahbaz, M.; Ozturk, I.; Afza, T.; Ali, A. Revisiting the Environmental Kuznets Curve in a Global Economy. Renew. Sustain. Energy Rev. 2013, 25, 494-502. [CrossRef]

56. Ozatac, N.; Gokmenoglu, K.K.; Taspinar, N. Testing the EKC Hypothesis by Considering Trade Openness, Urbanization, and Financial Development: The Case of Turkey. Environ. Sci. Pollut. Res. 2017, 24, 16690-16701. [CrossRef]

57. Acaravci, A.; Ozturk, I. On the Relationship between Energy Consumption, $\mathrm{CO}_{2}$ Emissions and Economic Growth in Europe. Energy 2010, 35, 5412-5420. [CrossRef]

58. Madaleno, M.; Moutinho, V. Analysis of the New Kuznets Relationship: Considering Emissions of Carbon, Methanol, and Nitrous Oxide Greenhouse Gases-Evidence from EU Countries. Int. J. Environ. Res. Public Health 2021, 18, 2907. [CrossRef] [PubMed]

59. To, A.H.; Ha, D.T.-T.; Nguyen, H.M.; Vo, D.H. The Impact of Foreign Direct Investment on Environment Degradation: Evidence from Emerging Markets in Asia. Int. J. Environ. Res. Public Health 2019, 16, 1636. [CrossRef]

60. Javid, M.; Sharif, F. Environmental Kuznets Curve and Financial Development in Pakistan. Renew. Sustain. Energy Rev. 2016, 54, 406-414. [CrossRef]

61. Murshed, M.; Alam, R.; Ansarin, A. The Environmental Kuznets Curve Hypothesis for Bangladesh: The Importance of Natural Gas, Liquefied Petroleum Gas, and Hydropower Consumption. Environ. Sci. Pollut. Res. 2021, 28, 17208-17227. [CrossRef]

62. Rabbi, F.; Akbar, D.; Kabir, S.M.Z. Environment Kuznets Curve for Carbon Emissions: A Cointegration Analysis for Bangladesh. Int. J. Energy Econ. Policy 2015, 5, 45-53.

63. Dong, K.; Sun, R.; Jiang, H.; Zeng, X. $\mathrm{CO}_{2}$ Emissions, Economic Growth, and the Environmental Kuznets Curve in China: What Roles Can Nuclear Energy and Renewable Energy Play? J. Clean. Prod. 2018, 196, 51-63. [CrossRef]

64. Ren, S.; Yuan, B.; Ma, X.; Chen, X. International Trade, FDI (Foreign Direct Investment) and Embodied $\mathrm{CO}_{2}$ Emissions: A Case Study of Chinas Industrial Sectors. China Econ. Rev. 2014, 28, 123-134. [CrossRef]

65. Farhani, S.; Lorente, D.B. Comparing the Role of Coal to other Energy Resources in the Environmental Kuznets Curve of three Large Economies. Chin. Econ. 2020, 53, 82-120. [CrossRef]

66. Saboori, B.; Sulaiman, J.; Mohd, S. Environmental Kuznets Curve and Energy Consumption in Malaysia: A Cointegration Approach. Energy Sources Part B Econ. Plan. Policy 2016, 11, 861-867. [CrossRef]

67. Saboori, B.; Sulaiman, J. Environmental Degradation, Economic Growth and Energy Consumption: Evidence of the Environmental Kuznets Curve in Malaysia. Energy Policy 2016, 60, 892-905. [CrossRef]

68. Marques, A.C.; Fuinhas, J.A.; Leal, P.A. The Impact of Economic Growth on $\mathrm{CO}_{2}$ Emissions in Australia: The Environmental Kuznets Curve and the Decoupling Index. Environ. Sci. Pollut. Res. 2018, 25, 27283-27296. [CrossRef]

69. Pata, U.K. The Influence of Coal and Noncarbohydrate Energy Consumption on $\mathrm{CO}_{2}$ Emissions: Revisiting the Environmental Kuznets Curve Hypothesis for Turkey. Energy 2018, 160, 1115-1123. [CrossRef]

70. Bilgili, F.; Kocak, E.; Bulut, U.; Kuloglu, A. The Impact of Urbanization on Energy Intensity: Panel Data Evidence Considering Cross-Sectional Dependence and Heterogeneity. Energy 2017, 133, 242-256. [CrossRef]

71. Kander, A.; Warde, P.; Henriques, S.T.; Nielsen, H.; Kulionis, V.; Hagen, S. International Trade and Energy Intensity during European Industrialization, 1870-1935. Ecol. Econ. 2017, 139, 33-44. [CrossRef]

72. Onafowora, O.A.; Owoye, O. Bounds testing approach to analysis of the environment Kuznets curve hypothesis. Energy Econ. 2014, 44, 47-62. [CrossRef]

73. Ahmed, K.; Ozturk, I.; Ghumro, I.A.; Mukesh, P. Effect of trade on ecological quality: A case of D-8 countries. Environ. Sci. Pollut. Res. 2019, 26, 35935-35944. [CrossRef] [PubMed]

74. Sulaiman, C.; Abdul-Rahim, A.S. Can clean biomass energy use lower $\mathrm{CO}_{2}$ emissions in African economies? Empirical evidence from dynamic long-run panel framework. Environ. Sci. Pollut. Res. 2020, 27, 37699-37708. [CrossRef]

75. World Bank. World Development Indicators; World Bank: Washington, DC, USA, 2021.

76. Ng, S.; Perron, P. Lag Length Selection and the Construction of Unit Root Tests with Good Size and Power. Econometrica 2001, 69, 1519-1554. [CrossRef]

77. Pesaran, M.H.; Shin, Y.; Smith, R.J. Structural analysis of vector error correction models with exogenous I(1) variables. J. Econ. 2001, 97, 293-343. [CrossRef]

78. Kripfganz, S.; Schneider, D.C. Response Surface Regressions for Critical Value Bounds and Approximate p-Values in Equilibrium Correction Models; Economics Department Discussion Papers Series, Paper number 19/01; University of Exeter: Exeter, UK, 2019. Available online: http:/ / people.exeter.ac.uk/RePEc/dpapers/DP1901.pdf (accessed on 18 March 2021).

79. Diao, X.; Zeng, S.; Tam, C.; Tam, V. EKC analysis for studying economic growth and environmental quality: A case study in China. J. Clean Prod. 2019, 17, 541-548. [CrossRef]

80. Gerundo, R.; Grimaldi, M.; Marra, A. A methodology hazard-based for the mitigation of the radon risk in the urban planning. UPLanD J. Urb. Plan. Landsc. Environ. Des. 2016, 1, 27-38.

81. Gerundo, R.; Nesticò, A.; Marra, A.; Carotenuto, M. Peripheralization Risk Mitigation: A Decision Support Model to Evaluate Urban Regeneration Programs Effectiveness. Sustainability 2021, 12, 8024. [CrossRef] 